УДК: 75.041 .5

ББК: 85.103(4)5

A43

DOI: $10.18688 /$ aal $17-5-55$

Giovanna Perini Folesani

\title{
Dominicus Who? Solving the Riddle Posed by a Splendid "Venetian" Portrait Dated 1512, at the State Hermitage Museum ${ }^{1}$
}

It takes some real quality for a Renaissance portrait to be able to hang close to Giorgione's Judith in the same museum room without fading or being overshadowed ${ }^{2}$ (Ill. 124). The high quality of this problematic picture is further proven by its seventeenth-century attribution to Giorgione (who died two years before it was painted) [70, I, p. 105; 15, p. 190]. It is no coincidence that this very portrait was chosen for the dust-jacket of the official catalogue in English of the Venetian paintings in the State Hermitage Museum published in the 1990s [31] and has recently travelled to Australia along with other masterpieces from St. Petersburg ${ }^{3}$. Still, its attribution and iconography have proven elusive so far.

Its current, yet not undisputed attribution to Domenico Capriolo, a minor Giorgionesque painter, is untenable on both stylistic and historical grounds ${ }^{4}$. A comparison with his one undisputed portrait of Lelio Torelli, signed and dated 1528 [23, XIX, pp. 210-211; 87, V, pp. 557-558; 77, XVI, pp.281-282; 89, IX/3, p.548, fig.374], shows that sixteen years later, far from improving as an artist, Domenico Capriolo (if he were the author of the State Hermitage picture) would paint in a stiffer, more elementary, much less imaginative and elegant way, having but a clumsy grasp on perspective. Comparisons with other questionable portraits occasionally at-

\footnotetext{
1 In memory of my mother, Fernanda Folesani Perini who loved portraits. I wish to thank Valerio Terraroli, Simone Signaroli and Annalisa Gnutti, from Brescia, and Maria Grazia Albertini Ottolenghi, from Pavia, for helping me in various ways, confirming facts, indicating relevant bibliography, suggesting ideas, supplying materials. Conclusions are nevertheless mine. I also wish to thank Carl Brandon Strehlke (Philadelphia Museum of Art) for allowing me to reproduce their picture and for providing background information and pics on other relevant paintings on the Johnson collection. The powerpoint shown during the conference in St. Petersburg can be found in my website on Researchgate.

2 Judith's stance happens to mirror the one of the Venus pudica in the portrait.

3 It was shown as Portrait of a Young Man by Domenico Capriolo at the National Gallery of Victoria, Melbourne, on the exhibition Masterpieces from the Hermitage. The Legacy of Catherine the Great held in 2015 (www.ngv.vic.gov.au/exhibition/masterpieces-from-the-Hermitage). This picture is neither listed nor discussed in [43], possibly because of lingering doubts about its attribution and meaning.

4 It has also been attributed, among others, to Domenico Mancini [23, LXVIII, p. 475; 91, pp. 244-246; 89, IX/3, pp. 488-490, fig. 322; 83, p. 116, note 131; 87, XXIII, p. 604], Palma Vecchio [36, pp.70, 74-75; 65, p. 153, n. V. 15; 49, p. 16; rejected by 75, p. 280, n. A34] and a fictitious "Master of Self-portraits" [92, pp. 97, 113-115]: its attribution to Capriolo is firmly rejected by Safarik [23, XIX, p. 211], following Adolfo Venturi. Von Hadeln does not even mention it in his short entry on Capriolo [87, V, pp.557-558], unlike its recent remake signed S. C. M., where it is called Portrait of a 25-year-old Man and confirmed to the painter [77, XVI, p. 281].
} 
tributed to Capriolo confirm that the State Hermitage picture is of a different cut, much above their standards. Nothing changes if - in quest for acceptable stylistic comparisons - we turn to the wider and much safer corpus of Capriolo's religious pictures. Their style is fairly consistent, but lacks originality and shows some peculiar ineptitude in composition, especially when it comes to staging archaeological remnants ${ }^{5}$. Mediocrity is Capriolo's hallmark ${ }^{6}$. Mediocrity is nowhere evident in the State Hermitage portrait, to the point that it was repeatedly copied in Northern Italy throughout the $16^{\text {th }}$ century, by more or less careful and gifted anonymous painters ${ }^{7}$. What struck them most was probably the elegance and originality of its invention and composition, regardless of which attribution it bore at their time.

The somewhat defiant stance of its smart sitter, standing in profile, thrusting his left arm across the window or balcony sill in the foreground and turning his face to confront the beholder (whether it was an entirely new idea or a brilliant reinvention after some lost Giorgionesque model), was to strike and inspire painters like Raphael, Palma, and the young Titian who immediately took it up and reworked it in various ways ${ }^{8}$. Thanks to them, it came down to other great artists of the following century such as Rembrandt and Le Brun who adopted it for their own self-portraits ${ }^{9}$. Indeed, this portrait has been occasionally mistaken for a self-portrait of its unlikely author, Domenico Capriolo [31, p. 118; 77, XVI, p. 281].

His name was first suggested by Harck in 1896 [31, p. 118], as the obvious solution for the riddle posed by a bronze medal painted as if encrusted into the sill and reading: "MDXII DOMINICUS - A[nno] XXV" around the figure of a sitting roebuck ("capriolo" in Italian) $)^{10}$. This roebuck is fairly similar to the one painted a few decades earlier by Jacometto at the back of his portrait of the Venetian nobleman Alvise Contarini (1443-1523: [23, XVIII, pp. 74-76]) as part of his personal emblem [54, p. 226; 51, p. 58; 66, pp. 240-243, n. 96; 3, I, p. 98 and II, p. 117;

\footnotetext{
5 See especially the allegorical picture sold at Sotheby's on July $11^{\text {th }}, 1979$, lot $\mathrm{n}$. 14 as Domenico Capriolo (subsequently attributed alternatively to Domenico Campagnola, Vincenzo Catena and, preposterously enough, even Lorenzo Lotto).

6 He is numbered "fra i più deboli rappresentanti dell'arte cinquecentesca in Treviso", which is quite provincial and marginal in its own right [89, IX/3, p. 545].

7 Lists of copies in [87, XXIII, p. 604; 36, pp. 69-74; pp. 208-209; 31, p. 119]. Of some interest is the unfaithful copy portraying Domenico de' Medici, painted and signed by "Antonio da Correggio" (aka Antonio Bernieri) and dated 1587, in the deposits of the Pinacoteca Malaspina, Pavia, unrecorded in [62; 93], but illustrated in the Museum files (inv. P 126) and in earlier, complete manuscript catalogues written in 1832 and 1900. (A visual reconstruction of the display of the Malaspina pictures in 1843 shows the portrait in a prominent position at eye level [62, p. 15]).

8 The relationship between the invention of this picture and Titian's portrait of a man in blue (aka L'Aretino) in the National Gallery, London is reversed by Charles Hope [75, p. 280, n. A 34], but see Gilbert [38, p. 205, n. 88] on a similar case: "It is natural to think Savoldo followed Titian, and he may well have done, but there is a good deal to be said for the converse view". Similar stances can be found in Palma's portraits [83, p. 116, n. 131; 77, XVI, p. 281] and in many pictures attributed to Giorgione. As for Raphael, suffice it to quote the double portrait of Navagero and Beazzano (1516) formerly in Pietro Bembo's collection [54, pp. 45-46; 51, p. 31; 5, pp. 260-261, n. 4.16 and 346; 41, p. 162 and 164, fig. 173]; Baldassarre Castiglione's portrait in the Louvre [41, p. 159 and 161, fig. 169] and most specifically the Portrait of a young man in Poland [41, pp. 170-171, fig. 180]. Even the famous portrait of Bindo Altoviti (1518) may be considered a further development of this seminal idea, in reverse [41, pp. 165-166, fig. 174].

9 For Le Brun's Self-portrait at the Uffizi see e.g. [71, pp.37-38, n.5]; for Rembrandt's Self-portrait dated 1640 at the National Gallery, London, see [82, pp. 385-387, n. 256].

10 Mistaken for a mule in $[75$, p. 280, n. A34].
} 
61, pp. 57v-58, figs. 45-46]. Still, given that the painter Domenico Capriolo was born in 1494, in 1512 he was not 25 , but merely 18 - which excludes that he is the sitter of the picture ${ }^{11}$, as much as he cannot be its painter, for this cannot be his signature [75, p. 280, n. A. 83]. In any case this is the portrait of a man of means, not of a young, obscure and rather inept artist.

The sitter is proud of his elegant attire, of his learning (shown by the bound booklet in his hands, possibly a collection of handwritten poems) and of his means (witnessed by his setting, within a palace boasting an arcade designed according to the updated principles of Renaissance architecture and hosting the statue of a headless and armless Venus pudica placed in a niche behind the sitter, possibly the most important item in his collection $)^{12}$. What can be seen beyond the arcade is a characteristic Quattrocento Venetian church placed in a field. The chimneys in the house beyond the church confirm that the location is somewhere within the vast borders of Venetian territories, but not in Venice. While this Venus is not listed in the survey of antiquities and collections from Venice and her territories drafted by Marcantonio Michiel between 1521 and 1543 [51; 54], it is pretty obvious that this is the portrait of a gentleman and a collector (a bit like Andrea Odoni, portrayed by Lotto and recorded by Michiel [54, pp. 152-164; 51, pp.51-53]), rather than of an artist or a dealer.

A vital clue to identify him is provided by a contemporary anonymous picture in the Philadelphia Museum of Art (Ill. 125) portraying possibly the same young gentleman, or possibly one of his close relatives (a brother or a cousin, for his features are very much alike), wearing similar garments boasting the very same bright colours arranged according to roughly the same pattern ${ }^{13}$. He is set against the background of a lake. Overgenerously ascribed to Boltraffio by Bernard Berenson when he sold it to an American wealthy lawyer, John G. Johnson [6, I, p. 173, n. $268 ; 47$, p. 3, n. 268$]^{14}$, this American picture was thought to be connected to Verona [48, pp. 13-14, n. 268], where the State Hermitage picture comes from: in fact, the latter was documented in the Muselli collection throughout the seventeenth century [70, I, p. 105; 15, p. 190; 25 , pp. 59, 61-62; 26, p. 194]. Yet, the lake behind the young man in the Philadelphia picture is easily identifiable as the Lake of Iseo, near Brescia, because of the peculiar shape of its shores, its surrounding mountains, and the small island featuring on a side (Montisola). Judging from the viewpoint taken, the young man is standing in Capriolo, a small village to the south of the lake, the original imperial fiefdom of the noble Brescian family of the same name (Capriolo or Caprioli), where they possessed an unadorned castle looking onto the now closed parish church of saints Gervasius and Protasius, rebuilt in the $19^{\text {th }}$ century $[30$, p. 54; 72, p. 222; 74,

11 This is deemed irrelevant in [31, p.119], but is agreed by many, e.g. [65, p. 153, n. V. $15 ; 75$, p. 280 , n. A34.]

12 I have not been able to identify it in [44, VIII/1, pp. 192-230 and VIII/2, pp. 132-150; 40, pp. 316-333; 9, pp. 59-64; 67, I, pp. 172-175, pls.339-345 and 317-345, pls.391-632; VI, pp.78-86, 175;] (see also note 26), although it is fairly close to a drawing by Pierre Jacques dated "1576" of a statue usually — but not undisputedly - identified with the Medici Venus. At the time this statue was probably in Rome, possibly in the Della Valle collection, but its origin is somewhat obscure [68, p. 124 and pl. 41 bis; 21, pp. 519-523, pl. 81; 40, pp. 325-328, n. $88 ; 9$, p. 61, n. 14$]$.

13 A portrait of the famous Elia Capriolo ascribed to Ferramola (still in the family possession [86, II, p. 476]) shows that lean, elongated faces with straight noses, arched eyebrows and high cheekbones were common family features.

14 Updated information is available in the on-line catalogue of the John G. Johnson Collection: www.philamuseum.org/collections/permanent/1012026.html?muIR=1631557143/111 (accessed 1 January 2017). The picture is not on display. 
p. 209]. The family also owned the nearby fiefdoms of Paratico, Sarnico and Palazzolo ${ }^{15}$. Their coat of arms originally featured a rampant yellow roebuck with a protruding red tongue against a pale blue ground. Thanks to an imperial decree, since the $17^{\text {th }}$ century this has been quartered with a black crow perched on a dark green branch of juniper, which is the coat of arms of the region of Valachia [22, I, p. 229; 46, I, p. 322; 85, App., I, pp. 508-509; 78, p. 6]. This refers to the military deeds of one Tommaso Capriolo, who, together with his brother Camillo, fought in the Flanders, Hungary, and Transylvania, where he was also appointed a governor [23, XIX, pp. 214-217; 73, pp. 451-456; 78, p. 6].

Gold yellow and dark red are the dominant colours of the clothes worn by both the State Hermitage gentleman and his American counterpart or relative, while light blue is the colour of the decoration of the bonnet and of the binding of the book in the State Hermitage portrait. They all happen to be part of their family livery and are among the noblest colours in the heraldic ranking ${ }^{16}$.

The Capriolo Brescian family, still extant [73, p. 225; 22, I, p. 229; 78; 46, I, p. 322; 85, App., I, p. 509; ignored by 7 and 45$]^{17}$, is totally unrelated to the painter identified by Harck, who just happens to be homonymous with them. It used to be a very large family, including several branches, most of them related by marriage with members of other equally prolific, multibranched and noble families from the same city, such as the Martinengos and the Avogadros. Many of the Capriolos became famous because of their writings, their military or diplomatic deeds, as hinted above, or their patronage of music [19, pp. 39-40, 146, 223-224, 239, 241; 63, I, pp. 234-237; 23, XIX, pp. 214-219; 73, pp. 158-159, 183-185, 217, 225-229, 269-270, 389-390, 443-445, 451-456; 58, p. 125; 88, pp. 19-20 and 95-96; 30, pp. 54, 70, 82, 89, 115, 228, 249]. The most famous man of letters is probably Elia Capriolo, who published a history of Brescia written in Latin in 1505 [17; 19, p. 146; 23, XIX, pp. 218-219; 73, pp. 183-185; 81, pp. 287-297]. At the time he was also in administrative charge of the building of the Loggia. He belongs to the generation before Domenico's. None of his known children bears this name ${ }^{18}$, but he had some brothers (Giovanni, Carlo, Angelo) [81, pp.288, n. 4 and 296] ${ }^{19}$ and four male cousins, including Luigi (or Alvise) [78, pp.4-6], who owned a famous collection of Roman antiquities

15 On the village of Capriolo see www.enciclopediabresciana.it/enciclopedia/index.php?title=CAPRIOLO, and also [30, p. 54]. Archaeological discoveries (bronze statues, coins) occasionally took place in the Capriolos' suburban properties: cf. [72, pp. 39-40; 74, p. 41]. As for Verona, Costanzo Capriolo (son of Camillo and Nosira Averoldi) was a governor in Verona, where he died in 1609 [78, p. 6]: he might have brought part of his family portraits with him.

16 The 1662 Muselli inventory [15, pp. 175-192, esp. 190] indicates it is a livery: "Un ritratto di Giorgione con un berettino bizzarro vestito a divisa di veluto e broccato, con un ferraiolo foderato di pelli di volpe con architettura et una statua di marmo senza testa, con tutte due le mani tiene un libro: è maggiore del naturale et è il più bel quadro che si sappi di Giorgione" (italics mine). As for the ranking and meaning of red and yellow in Italian coats-of-arms, see contemporary handbooks such as [53, pp. 17-25, 47-51, 57-58] and [79, fols. 5r-6r, $7 \mathrm{r} / \mathrm{v}, 11 \mathrm{v}-13 \mathrm{r}, 17 \mathrm{r}-18 \mathrm{v}, 24 \mathrm{r} / \mathrm{v}, 27 \mathrm{r} / \mathrm{v}$ and passim]. Incidentally, these are the same colours of the Bentivoglios in Bologna, even if the Philadelphia picture has been wrongly connected with the Pepolis (also from Bologna, not Verona) [48, pp. 13-14, n. 268], whose colours are black and white in a chequered pattern. On contemporary dress code in Brescia, see [13], where the present picture is also illustrated.

17 See also www.enciclopediabresciana.it/enciclopedia/index.php?title=CAPRIOLI.nobili (accessed 1 January 2017).

18 Their names are: Marcantonio (†1507), Girolamo, Quinto Probo [81, pp. 295, 297, 309].

19 Angelo must have had no offsprings, for he was a Carmelitan friar [73, pp. 225-229; 81, p. 296; 78, p. 4]. 
$[84, \text { p. } 19]^{20}$. Domenico must have been the offspring of one of these ${ }^{21}$. Notwithstanding the literary and social ambitions shown in his portrait, Domenico failed to gain eternal fame for himself. He may have died young, shortly after this portrait was completed. If this is the case, there is some tragic irony in it.

The year 1512 was not an ordinary year in the history of Brescia (and of the Capriolos). As a city state, after a short period under Milanese rule, in 1426 Brescia chose to become part of the neighbouring Venetian Republic [4; 34, pp. 59-63; 86, II, pp. 26-78, 227-296; 56, pp. 105-106; 88, esp. 27-65]. In 1509, it surrendered to the French troops, and some of its noblemen (including Girolamo, son of Bartolomeo Capriolo, and his nephew Costanzo) were bestowed aristocratic titles by the King of France Louis XII. Some years later, the city rose up in arms against the French, dispelled them, but, after a short siege, it was conquered again by the troops of Gaston de Foix-Nemours, a relative of the French King. They ransacked and looted it between February $19^{\text {th }}$ and $24^{\text {th }} 1512$ [84, pp. 289-296; 86, II, pp. 259-270; 35]. Over ten thousand people died. Many noblemen (especially the ones more involved with the Venetian ruling or faithful to it) were beheaded. Others, like Elia Capriolo and his branch of the family, had to pay a ransom [81, pp. 295-296]. Everybody lost money, gems, silverware, art collections [64, p. 30] - whatever could be taken away, on top of life and honour. Costanzo Capriolo lost the document proving his newly acquired French title [85, App., I, pp. 508-509] $]^{22}$. After the sack, everybody (especially people with means) left the city and fled to the countryside or the hills, wherever they had possessions, in order to survive the plague raging in the city, whose streets and churches were strayed with unburied corpses. Meanwhile, Gaston the Foix and his troops also left the Brescian territory, heading to the south-east. A couple of months later, in April, Gaston de Foix was seriously wounded during the battle of Ravenna and died a few days later.

Thus, the portrait of this twenty-five year-old Brescian aristocrat named Domenico Capriolo (or Caprioli) was painted in the spring of $1512^{23}$, in the aftermath of the sack of his city and possibly of the French general's death. The fur-lined coat haphazardly hanging from his right shoulder and the bright green grass in the countryside indicate that the long, dire winter is finally over. In this context, his defiant stance acquires its full meaning. A lucky survivor, he is making a point: he is not just a survivor, he stands unbent, his means and his collections are virtually unscathed, and he can look forward to a brighter future. As for his totemic symbol in the bronze medal, the roebuck quietly lying down rather than being rampant, it might be no coincidence if it looks like Alvise Contarini's personal emblem. Some Contarinis from Venice held offices in Brescia. In particular, Domenico Contarini had been the captain of Brescia at

20 On Brescian collections of antiquities and antiquarian studies, see also [1;29, pp.177-178; 37; 59; 64, pp. 30-32]

${ }_{21}$ The Capriolo family tree partly drawn in [78] has several incomplete branches, especially in the $15^{\text {th }}$ and early $16^{\text {th }}$ century. Suffice it to say that there is no mention of Elia's offspring, that his cousin Luigi's is deemed incomplete and includes only a son and a daughter and that we cannot be sure if the lists of the children of Luigi's brothers Bartolomeo, Antonio and Francesco are complete. It is worth checking in Brescia, in the papers of the Capriolo family archive, to which [78] had no access.

22 Amidst the local chroniclers of the Sack there is one Faustino Caprioli [35, II].

23 In Brescia, Venetian chronology (which is different from ours, for up to 1797 the new year would start on March $1^{\text {st }}$ ) is rarely used before mid- $16^{\text {th }}$ century. However, this is irrelevant for the true date of this picture, because after March $1^{\text {st }}$ Venetian chronology and ours always coincide [16, pp. 11-12, 341]. 
the beginning of the previous decade [23, XXVIII, pp. 139-142, esp. 140; 80, p. 53]. When he left office, he was presented with an elegant manuscript dated September $13^{\text {th }} 1505$, the copy of an imperial privilege to the city allegedly granted by the first Holy Roman Emperor, Charles the Great (Carolus Magnus) [80]. When he had first seen the original manuscript during a survey of the Brescian territory, he was accompanied by a group of Brescian noblemen, including Francesco Capriolo, obviously some relative of Domenico's [80, p. 54]. Whether deeper links have run between the Contarinis and the Capriolos, it is not known at present. The coincidence of the first names of the mature Venetian aristocrat and of the young Brescian nobleman in the portrait may be just fortuitous ${ }^{24}$. The Capriolos moved from their original fiefdom to Brescia in the $14^{\text {th }}$ century when they built their palace, still standing in the city centre $[2$, p. $19 ; 14$, p. 175 ; 76, p. 111].

A model for architects in the age of Eclecticism [69, pl. V], it still shows $14^{\text {th }}$ century features, but it does not include any arcade resembling the one in the picture, showing Corinthian capitols reminiscent of the ancient ones from the Roman Theatre in Brescia, at the time part of the Maggi family palace (later to house the Gambaras) [11]. Although the Capriolo palace looked onto the adjoining church and convent of Santa Maria delle Grazie, which was part of the same block and has undergone several changes over the centuries [52, pp.384-405], the suburban setting of the view in the portrait may indicate that it is set inside the namesake fortress of Capriolo, imaginatively refurbished for the occasion and looking onto the aforesaid church of Saints Gervasius and Protasius.

As for the Venus pudica depicted therein, it is hard to identify it. It is neither mentioned nor reproduced in Rossi's account of Brescian antiquities [72; 74], which must mean that a century later it was long gone and forgotten. It looks fairly close to the one allegedly unearthed in Rome, now universally known as Medici Venus in the Uffizi. Pierre Jacques' drawing after it, dated 1576 , shows what it looked like before undergoing thorough restoration, but after her originally severed head had already been put back into place [68, p. 124 and pl.41bis]. More interestingly, the same Brescian Venus, reshaped into a living figure of elongated, Mannerist proportions stepping out of a similar niche in the wall, may have been the model for the picture now in the Borghese Gallery in Rome, invented by a very mediocre Tuscan painter sometime around 1520 [90, IX/V, pp.371-372 and fig. 202; 20, II, pp.19-20, fig and entry 17; 55, p. 238, n. $4^{25}$ ]. Officially named Andrea di Giovanni Antonio Piccinelli, he worked as a painter in both Siena and Florence, but he had been born in Brescia from Brescian parents in 1487 - hence, his nickname, Brescianino. He happened to be the very same age as the sitter of the State Hermitage portrait, and his first training as an artist must have taken place in his native city $^{26}$.

24 The same may apply to the harts marking the Civran and Contarini estate properties in Venice: https://venicewiki.org/wiki/scultura-esterna (Jan. 2017) (especially the slabs marked CN12 and CN114, DD338, CS224(l) and 278).

25 A very similar statue of Venus (featuring restored head, legs and one arm) is also depicted in a contemporary allegorical painting formerly in Dresden, known as The Astrologist, by an anonymous Venetian painter of the $16^{\text {th }}$ century: see [65, p. 152, n. V. 9 and fig. 237].

26 He had been in Tuscany since 1505, active mostly in Siena, but also in Florence. Thus he may have met Savoldo in 1508 [8; 90, IX/V, pp.357-373; 33]. His portrait of a youth in Philadelphia [90, IX/V, pp. 368-369, fig. 200] is vaguely reminiscent of Raphael's portraiture, as much as of Andrea del Sarto's - and of the State Hermitage portrait. 
Like many Brescian expats, he may have gone back to Brescia shortly after the sack, to check on his family and/or possessions: he may have seen the statue on that occasion, or he may have had youthful memories of it, or he may have acquired drawings after it from fellow Brescians in Central Italy like, say, Giovanni Antonio da Brescia [23, LVI, pp. 281-285] who made a living by copying ancient statues as soon as they were unearthed in Rome, be they the Laocoon or the Mazarin Venus ${ }^{27}$. Hosts of great artists throughout Italy, from Benozzo Gozzoli, to Raphael and Michelangelo would also copy such antiquities ${ }^{28}$.

Still, this tells us nothing about the author of the Capriolo portrait. There is no question that he is a good, even a great artist. Brescia has a long-standing tradition of competent and even excellent native portrait painters, from Romanino to Moretto. Other Lombard painters, like Altobello Melone, also portrayed Brescian nobility, and so did several Venetian painters, including Bartolomeo Veneto [57], although none of them was probably back to Brescia until 1516, when the city was finally reunited to the Venetian Republic. There is one great Brescian painter of whom we know nothing between December, 1508 (when he registered as a master in the painter's guild in Florence) [58, pp.39-41; 60, pp.26, 316-317] and 1521, when he was documented in Venice, summoned to Treviso to complete an altarpiece which had been left unfinished by Marco Pensaben [60, pp. 94-97, n. I. 1]. In 1521, this painter, named Giovan Girolamo Savoldo, was about thirty-nine or older [87, XXIX, pp. 510-512; 89, IX/3, pp. 745-749; 12, pp. 1016-1035; 58, p. 26; 60, p.316, ad annum 1498]. Possibly a member of the lesser Brescian nobility [72, p. 502; 58, pp. 13-19; 2, p. 180], he did not start painting that late. He may be put forth as a likely candidate for the State Hermitage portrait by default.

Conversant with Tuscan and Roman painting, as much as with the Venetian and Lombard schools (he was in Parma in 1506, already a master) [60, p. 316 ${ }^{29}$, he had at least a smattering of Flemish painting too. (He was married to a Flemish woman, of whom we know little but her first name, Maria. We may wonder whether she came from a family of painters, for Flemish influence is obvious in some of Savoldo's works) [58, pp.26, 32, 35; 60, pp. 20-21, 87-89; 27; $50]^{30}$. His later, well known ability to render the lustre of shining silks and shimmering velvets

\footnotetext{
27 See also The Warburg Institute Iconographic Database - Gods \& Myths - Venus at: http://warburg.sas. ac.uk/vpc/VPC_search/subcats.php?cat_1=5\&cat2=43 (Jan. 2017).

28 See e.g. The Warburg Institute Iconographic Database at: http://warburg.sas.ac.uk/vpc/VPC_search/subcats.php?cat_1 $=5 \&$ cat $2=43 \&$ cat_3=1538\&cat_4=1940\&cat_5=1867 (Jan. 2017).

29 Connections between Emilian sovereign city states (e.g. Carpi and Correggio) and Brescia are numerous, especially thanks to the family relations between the Gambaras and both the Pio da Carpis and the da Correggios, but in the case of Parma its Brescian links (later bolstered by the Rossi family, originating in Parma) have something to do with the Capriolos, namely with Timotea Capriolo (†1490), a sister of Alvise's and a cousin of Elia's, Augustinian prioress first in Parma, then in her native city, in the newly established church of Santa Croce, where she was summoned by her brother Bartolomeo [24, pp. 10 note 23, 18-23, 26, 32, 37, 46, 76, 82]. This may partly account for Savoldo's documented stay in Parma in 1506, especially considering that another Capriolo, named Francesca, became prioress in Santa Croce after Timotea's death, supervising the completion of the church and its painterly decoration, including Savoldo's Deposition, later in Berlin [24, pp. 32, 34-38; 32, pp. $113-115$, n. 35; 18, p. 81]. Francesca $(\dagger 1516)$ was still the head of the monastery in 1512, during the Sack [24, pp. 38-39, 41-42]. For the role played by prioresses and abbesses in Italian early Cinquecento convents and for their art patronage, see [61].

30 In fact we also know that she was a widow with two children, probably from Tiel (a village not far from where Bosch was born and lived, today known as Bois-le-Duc or s' Hertogenbosch) [50, p. 78]. Her previous husband might have been either an Italian tradesman, or a Flemish merchant, craftsman or artist [60, p. 319].
} 
finds a timid prelude in this picture, in the brocade of the sitter's jacket. On the other hand, the architectural setting in this picture features grey stone, foreign to Brescian tradition, where white marble and bricks are more common. It points rather to Florentine or central Italian architecture, anticipating Bronzino.

The painter's apparent ability to portray characters, as well as facial features, may recall Andrea del Sarto (one of Piero di Cosimo's most gifted pupils), as much as earlier and contemporary Venetian and Lombard portraits. The style of this picture matches no extant portrait by either the best Florentine, or the most prestigious Lombard and Venetian painters of the time. Indeed, a recent London exhibition on Giorgione proves just how vague and contradictory the reconstruction of the latter's oeuvre still is [28, pp. 36-69, nos. 1-15]. Because of its undeniable qualities $^{31}$, this portrait may well be the earliest known work of a great painter who was later to assume a better defined, stronger personality. Of course, this is no debut, but it may become the starting point to reconstruct Savoldo's oeuvre in his early years on a different, possibly firmer ground $^{32}$.

\section{References}

1. Albertini A. Brescia città romana - Iscrizioni. Brescia romana - Materiali per un museo, 1. B. Passamani (ed.). Brescia, Grafo Publ., 1979, pp. 151-179 (in Italian).

2. Averoldi G. A. Le scelte pitture di Brescia additate al Forestiere. Brescia, Rizzardi Publ., 1700. 300 p. (in Italian).

3. Baetjer K. European Paintings in the Metropolitan Museum of Art by Artists Born in or before 1865. New York, The Metropolitan Museum of Art Publ., 1980. 528 p.

4. Bauce F. Crescita e declino economico in una città di Antico Regime - Il caso di Brescia tra la fine del Quattrocento e la seconda metà del Cinquecento. Ph. D. thesis. Verona, University of Verona, 2009, supervisors Profs M. Pegrari and E. Demo. 684 p. (in Italian).

5. Beltramini G.; Gasparotto D.; Tura A. Pietro Bembo e l'invenzione del Rinascimento. Venice, Marsilio Publ., 2013. 440 p. (in Italian).

6. Berenson B. Catalogue of a Collection of Paintings and Some Art Objects - Italian Paintings. Philadelphia, John G. Johnson Publ., 1913. 466 p.

\footnotetext{
Also the Capriolos had close family ties with the Flanders, centuries before some served with Alessandro Farnese in the war waged by Spain in the $16^{\text {th }}$ century [73, pp. 225,443$]$.

31 The imposing proportions of the sitter in relation to his [architectural] setting do not depend on ineptitude in perspective [31, p. 119], as they are a deliberate rhetorical device, an emphatic trait dear to "early" Savoldo (among others), as already remarked in [12, p. 1018]. Indeed, this can be observed in the Washington Elijah, the Venice Hermits and his several Magdalens, of course, but also in the Louvre so-called Gaston de Foix, in the New York St. Matthew, and in many of his portraits and genre pieces, e.g. [32, pp. 30-32, n. 3; pp. 33-35, n. 4; pp. $96-105$, nos. 28-31; pp. 54-56, n. 12; pp. 82-83, n. 23]; as for the portraits etc. [32, pp. 106-108, n. 32; p. 74, n. 19; pp.75-76, n. 20; pp.111-112, n. 34; pp.122-126, nos. 38-39]. I will add here the much debated St. Paul hanging on the chimney piece in the dining-room of [Sir] Anthony Blunt's former private apartment at 20, Portman Square (once the Courtauld Institute of Art, London), where Michael Kitson would teach British Art in the academic year 1983-1984 [32, pp. 144-145, n. 1A].

32 Longhi's haphazard reconstruction of Savoldo's "Lombard" beginnings, vehemently upheld by his immediate followers [10], is no longer given full credit by his later heirs, nor by the scholarly community at large: e.g. [32, p. 7; 33; 58, pp. 26, 28-29, 32; 60, pp. 38, 52, 87-91]. As Gilbert puts it, "sono destinati a fallire i tentativi dei critici che cercano il Savoldo giovane partendo dalla sua maturità per scoprirne, sulla scorta delle opere ad essa pertinenti, le manifestazioni giovanili, come hanno fatto tutti, dal Longhi al Suida [...]. Il giovane Savoldo, sembra, era un altro. Non è un caso isolato, perché ha un parallelo interessantissimo nel primo Tiziano" (italics mine) $[39$, p. 47].
} 
7. Bertucci T. Almanacco Nobiliare Italiano - Edizione aggiornata delle Casate Nobili d'Italia, pubblicata in occasione del Centenario dell'Unità d'Italia, 1861-1961. Milan, Edizioni Dora Publ., 1961. 356 p. (in Italian).

8. Bisogni F. Piccinelli Andrea detto il Brescianino in La pittura in Italia - Il Cinquecento, 2. Milan, Electa Publ., 1988, p. 804 (in Italian).

9. Bober P. P.; Rubinstein R. O. Renaissance Artists and Antique Sculpture, A Handbook of Sources. London; Oxford, Harvey Miller — Oxford University Press Publ., 1986. 522 p.

10. Boschetto A. Giovan Gerolamo Savoldo. Milan, Bramante Publ., 1963. 246 p. (in Italian).

11. Boschi R.; Stradiotti A. Le rovine romane nella città medievale - Il Palazzo Maggi-Gambara nell'area del teatro romano di Brescia. Brescia romana - Materiali per un museo, 2. Brescia, Grafo Publ., 1979, pp. 69-97 (in Italian).

12. Bossaglia R. La pittura bresciana del Cinquecento: i maggiori e i loro scolari. Storia di Brescia. Brescia, Morcelliana/Fondazione Treccani degli Alfieri Publ., 1963-1964, pp. 1011-1101(in Italian).

13. Bridgeman J. I santi "gagliardi cavalieri - Vesti e armature nell'iconografia dei Santi Faustino e Giovita del Moretto. Ferramola e Moretto. Le ante d'organo del Duomo Vecchio di Brescia restaurate. M. Capella; I. Gianfranchi; E. Lucchesi Ragni (eds.). Brescia, Grafo Publ., 2004, pp. 65-67 (in Italian).

14. Brognoli P. Nuova guida per la città di Brescia. Brescia, Nicoli Cristiani Publ., 1826. 349 p. (in Italian).

15. Campori G. Raccolta di cataloghi ed inventari inediti di quadri, statue, disegni, bronzi dorerie, smalti, medaglie, avori ecc. dal secolo XV al secolo XIX. Modena, Vincenzi Publ., 1870. 712 p. (in Italian).

16. Cappelli A. Cronologia, cronografia e calendario perpetuo daò principio dellera cristiana ai nostri giorni. Milan, Hoepli Publ., 1978. 696 p. (in Italian).

17. Capriolo E. Chronica de Rebus Brixianorum ad Senatum Populumque Brixianum. Brescia s. d. [1505], 74 fols (= 148 p.) (in Latin).

18. Chizzola L.; [Carboni G. B.]. Le pitture e sculture di Brescia che sono esposte al pubblico. Brescia, Bossini Publ., 1760. 196 p. (in Italian).

19. Cozzando L. Libreria bresciana. Brescia, Rizzardi Publ., 1685. 338 p. (in Italian).

20. Dalla Pergola P. Galleria Borghese - I dipinti, 2 vols. Rome, Istituto Poligrafico dello Stato Publ., 1955-1959. (in Italian).

21. Di Cosmo L.; Fatticcioni L. Le regole della bellezza - Saperi antiquari e teorie dellarte nei "Segmenta Nobilium Signorum et Statuarum" di François Perrier. Naples, La Stanza delle Scritture Publ., 2012. 671 p. (in Italian and Latin).

22. Di Crollalanza G. B. Dizionario storico-blasonico delle famiglie nobili e notabili italiane estinte e fiorenti, 3 vols. Fermo, presso il Giornale Araldico Publ., 1886-1890 (in Italian).

23. Dizionario Biografico degli Italiani, 85 vols., in progress. Rome, Istituto della Enciclopedia Italiana Publ., 1960 (in Italian).

24. Doneda C. Notizie istoriche del Monastero di Santa Croce di Brescia. Brescia, Bossini Publ., 1764. 212 p. (in Italian and Latin).

25. Dossi D. I quadri già Muselli all'Ermitage: precisazioni su alcune provenienze. Verona Illustrata, 2013, vol. 26, pp. 49-66 (in Italian).

26. Dossi D. La collezione Muselli di Verona - La quadreria negli anni Ottanta del Seicento. Studi di storia dellarte, 2014, vol.25, pp. 187-198 (in Italian).

27. Ebert-Schifferer S. Il Savoldo e il Nord. Un processo di appropriazione. Giovan Gerolamo Savoldo tra Foppa, Giorgione e Caravaggio. B. Passamani (ed.). Milan, Electa Publ., 1990, pp.71-77 (in Italian).

28. Facchinetti S.; Galansino A. In the Age of Giorgione. London, Royal Academy of Arts Publ., 2016, entries nn. 1-15, pp. 36-69.

29. Favaretto I. Arte antica e cultura antiquaria nelle collezioni venete al tempo della Serenissima. Rome, l'Erma di Bretschneider Publ., 1990. 414 p. (in Italian).

30. Ferraro J. M. Family and Public Life in Brescia, 1580-1650. The Foundations of Power in the Venetian State. Cambridge, Cambridge University Press, 2003. 258 p.

31. Fomicheva T. D. The Hermitage - Catalogue of Western European Painting, Venetian Painting Fourteenth to Eighteenth Centuries. Florence; Moscow, Giunti and Iskusstvo Publ., 1992. 406 p.

32. Frangi F. Savoldo - Catalogo completo. Florence, Cantini Publ., 1992. 159 p. (in Italian).

33. Frangi F. Savoldo, Giovan Girolamo. La pittura in Italia - Il Cinquecento, vol. 2. G. Briganti (ed.). Milan, Electa Publ., 1988, pp. 833-834 (in Italian).

34. Frati V.; Massa R.; Piovanelli G.; Robecchi F. Brescia. Bari, Laterza Publ., 1989. 232 p. (in Italian). 
35. Frati V.; Gianfranceschi I.; Bonali Fiquet F.; Perini Bianchi I.; Robecchi F.; Zilioli Faden R. Il sacco di Brescia, 3 vols. Brescia, Grafo Publ., 1990. (in Italian).

36. Garas K. Giorgione et giorgionisme au XVII siècle - III. Bulletin du Musés Hongrois des Beaux Arts, 1966, vol. 28, pp. 69-93 (in French).

37. Garzetti A. Le iscrizioni romane di Brescia. Brescia romana - Materiali per un museo, 1. B. Passamani (ed.). Brescia, Grafo Publ., 1979, pp. 181-189 (in Italian).

38. Gilbert C.E. Giovanni Girolamo Savoldo. The Genius of Venice, 1500-1600. J.Martineau; C. Hope (eds.). London, Royal Academy of Arts - Weidenfeld and Nicolson Publ., 1983, pp. 202-206.

39. Gilbert C. E. Savoldo cortese. Giovan Gerolamo Savoldo tra Foppa, Giorgione e Caravaggio. B. Passamani (ed.). Milan, Electa Publ., 1990, pp.38-47 (in Italian).

40. Haskell F.; Penny N. Taste and the Antique. New Haven; London, Yale University Press, 1981. 376 p.

41. Jones R.; Penny N. Raphael. New Haven; London, Yale University Press, 1983. 256 p.

42. Kultzen R.; Eikemeier P. (eds.). Bayerische Staatsgemäldesammlungen Alte Pinakothek, München - Gemäldekataloge - Venezianische Gemälde des 15. Und 16. Jahrhunderts. München, Bayerische Staatsgemäldesammlungen Publ., 1971, pp. 208-209 (in German).

43. Kustodieva T. Museo Statale Ermitage - La pittura italiana dal XIII al XVI secolo. Milan, Skira Publ., 2011. 268 p. (in Italian).

44. Lexicon Iconographicum Mythologiae Classicae (LIMC). Zürich; Düsseldorf, Artemis Publ. (in various European languages, mostly Italian, German and French).

45. Litta P. Famiglie celebri italiane, 12 vols. Milan, Giusti Publ., 1819. (in Italian).

46. Mannucci S. Nobiliario e blasonario del Regno d'Italia, 5 vols. Rome, Collegio Araldico, s. d. (in Italian).

47. Marceau H. John G. Johnson Collection, Catalogue of Paintings. Philadelphia, s.n.t., 1941. 73 p.

48. Marceau H. John G. Johnson Collection, Catalogue of Italian Paintings. Philadelphia, s.n.t., 1966. 247 p.

49. Mariacher G. Palma il Vecchio. Milan, Bramante Publ., 1968. 248 p. (in Italian).

50. Meijer B. W. Fiamminghi nella Serenissima nel primo Cinquecento. Giovan Gerolamo Savoldo tra Foppa, Giorgione e Caravaggio. B. Passamani (ed.). Milan, Electa Publ., 1990, pp. 78-86 (in Italian).

51. Michiel M. A. Notizie d’opere del disegno, ed. by T.Frimmel (1896). Florence, Edifir Publ., 2000. 64 p. (in Italian).

52. Morassi A. Catalogo delle cose d'arte e d'antichità d'Italia - Brescia. Rome, La Libreria dello Stato Publ., 1939. 549 p. (in Italian).

53. Morato F. P. Del significato de' colori e de' mazzoli. Mantua, Osanna Publ., 1581. 84 p. (in Italian).

54. Morelli J.; Frizzoni G. Notizia di opere di disegno. Bologna, Zanichelli Publ., 1884. 266 p. (in Italian).

55. Moreno P.; Stefani C. Galleria Borghese. Milan, Touring Club Italiano Publ., 2000. 415 p. (in Italian).

56. Nova A. La pittura nei territori di Bergamo e Brescia nel Cinquecento. La pittura in Italia - Il Cinquecento. G. Briganti (ed.). Milan, Electa Publ., 1988, I, pp. 105-124 (in Italian).

57. Pagnotta L. Bartolomeo Veneto. Lopera completa. Florence, Centro Di Publ., 1997. 360 p. (in Italian).

58. Panazza G. (ed.). Giovanni Gerolamo Savoldo pittore bresciano. Brescia, Ed. del Moretto-Ateneo di Brescia Publ., 1985. 192 p. (in Italian).

59. Passamani B. La coscienza della romanità e gli studi antiquari tra Umanesimo e Neoclassicismo. B. Passamani (ed.) Brescia romana - Materiali per un museo, 2. Brescia, Grafo Publ., 1979, pp. 5-49 (in Italian).

60. Passamani B. (ed.). Giovan Gerolamo Savoldo tra Foppa, Giorgione e Caravaggio. Milan, Electa Publ., 1990. 356 p. (in Italian).

61. Periti G. In the Courts of Religious Ladies. Art, Vision and Pleasure in Italian Renaissance Convents. New Haven; London, Yale University Press, 2015. 294 p.

62. Peroni A.; Vicini D.; Nepoti S. Pavia - Pinacoteca Malaspina. Pavia, Comune di Pavia Publ., 1981. 252 p. (in Italian).

63. Peroni V. Biblioteca bresciana. Opera postuma, 3 vols. Brescia, Bettoni Publ., 1818 (in Italian).

64. Piazza F. Quattro secoli di collezionismo a Brescia. Moretto, Savoldo, Romanino, Ceruti - Cento capolavori dalle collezioni bresciane. D. Dotti (ed.). Cinisello Balsamo, Silvana Editoriale Publ., 2014, pp.30-41 (in Italian).

65. Pignatti T. Giorgione - L’opera completa. Milan, Alfieri-Electa Publ., 1978. 356 p. (in Italian).

66. Pope-Hennessy J. The Robert Lehman Collection - Italian Painting. Princeton, Princeton University Press, 1987. $331 \mathrm{p}$.

67. Reinach S. Répertoire de la statuaire grecque et romaine, 6 vols. Paris, Leroux Publ., 1897-1930 (in French). 
68. Reinach S. L'Album de Pierre Jacques Sculpteur de Reims dessiné à Rome de 1572 à 1577. Paris, Leroux Publ., 1902. 147 p.; 99 pls. (in French).

69. Ricordi di architettura raccolti, autografati e pubblicati da una società di architetti fiorentini. 1880, vol.3, fasc. XII, pl. V (in Italian).

70. Ridolfi C. Le maraviglie dellarte, ovvero le vite degli illustri pittori veneti e dello Stato (1914-1924), 2 vols. D. von Hadeln (ed.). Rome, Società Multigrafica editrice Publ., 1965. (in Italian and German).

71. Rosenberg P. Pittura francese nelle collezioni pubbliche fiorentine. Florence, Centro Di Publ., 1977. 296 p. (in Italian).

72. Rossi O. Le memorie bresciane. Brescia, Fontana Publ., 1616. 347 p. (in Italian).

73. Rossi O. Elogi historici di Bresciani illustri - Teatro. Brescia, Fontana Publ., 1620. 519 p. (in Italian).

74. Rossi O. Le memorie bresciane, opera historica e simbolica. F. Vinaccesi (ed.). Brescia, Gromi Publ., 1693. 338 p. (in Italian).

75. Rylands Ph. Palma il Vecchio. L'opera completa. Milan, Mondadori Publ., 1988. 336 p. (in Italian).

76. Sala A. Pitture ed altri oggetti di Belle Arti di Brescia. Brescia, Cavalieri Publ., 1834. 178 pp. (in Italian).

77. SAUR Allgemeines Künstlerlexikon. Die Bildenden Künstler aller Zeiten und Völker. Munich; Leipzig, 1983 (in progress).

78. Schullern-Schrattenhofen E. von. La nobile famiglia Caprioli di Brescia. Rivista Araldica, 1928, vol. 26, pp. 3-8 (in Italian).

79. Sicillo Araldo. Trattato dei colori nellarme, nelle livree e nelle divise. Venezia, Spineda Publ., 1606. 22 fols.; 44 p. (in Italian).

80. Signaroli S. La leggenda nel Rinascimento: il manoscritto Cicogna 1140. La leggenda di Carlo Magno nel cuore delle Alpi. Ricerca storica e turismo culturale. G. Azzoni (ed.). Cinisello Balsamo, Silvana Editoriale Publ., 2012, pp. 53-57 (in Italian).

81. Signaroli S. Brescia, Venezia, Leida. I Chronica di Elia Capriolo nella Respublica Literaria dell'Europa moderna. Italia medievale e umanistica, 2008, vol. 49, pp. 287-329 (in Italian).

82. Slatkes L. J. Rembrandt - Catalogo completo. Florence, Cantini Publ., 1992. 495 p. (in Italian).

83. Spahn A. Palma Vecchio. Leipzig, Hiersemann Publ., 1932. 222 p. (in German).

84. Spini P. Delle historie bresciane. Brescia, Marchetti Publ., 1585. 344 p. (in Italian).

85. Spreti V. Enciclopedia storico-nobiliare italiana - famiglie nobili e titolate viventi, $6+2$ vols. Milan, Edizioni dell'Enciclopedia Storico-Nobiliare italiana Publ., 1928-1936; Appendice. Milan, Stirpe Publ., 1935 (in Italian).

86. Storia di Brescia, II, La dominazione veneta (1426-1575). Brescia, Morcelliana/Fondazione Treccani degli Alfieri Publ., 1963-1964. 1124 p. (in Italian).

87. Thieme F.; Becker U. Allgemeines Lexikon der bildenden Künstler, 37 vols. Leipzig, Seemann Publ., 1907-1947 (in German).

88. Valseriati E. Tra Venezia e l'Impero - Dissenso e conflitto politico a Brescia nelletà di Carlo V. Milan, Franco Angeli Publ., 2016. 198 p. (in Italian).

89. Venturi A. Storia dellarte italiana - IX - La pittura del Cinquecento, III. Milan, Hoepli Publ., 1928. 1069 p. (in Italian).

90. Venturi A. Storia dell'arte italiana - IX - La pittura del Cinquecento, V. Milan, Hoepli Publ., 1932. 939 p. (in Italian).

91. Venturi L. Giorgione e il Giorgionismo. Milan, Hoepli Publ., 1913. 403 p. (in Italian).

92. Wilde J. Die Probleme um Domenico Mancini. Jahrbuch der Kunsthistorischen Sammlungen in Wien, 1933, vol. 7, pp. 97-136 (in German).

93. Zatti S. Musei Civici di Pavia - La Pinacoteca Malaspina. Milan, Skira Publ., 2011. 336 p. (in Italian).

Title. Dominicus Who? Solving the Riddle Posed by a Splendid "Venetian" Portrait Dated 1512, at the State Hermitage Museum.

Author. Giovanna Perini Folesani - full professor (of History of Art Literature). DISTUM (Dipartimento di Studi Umanistici), University of Urbino “Carlo Bo", Palazzo Albani, Via Bramante, 17, 61029 Urbino, Italy. giovanna.perini@uniurb.it

Abstract. The splendid portrait in the State Hermitage Museum dated 1512, usually attributed to Domenico Capriolo (1494-1528), is, in fact, a riddle. The bronze medal painted on the window sill showing a crouching roebuck (capriolo in Italian) surrounded by the inscription "MDXII - Dominicus - A.XXV" is generally mistaken for a signature and referred to its painter, sometimes identified as the sitter as well, regardless of the 
fact that by 1512 the painter Domenico Capriolo from Treviso should have been 18 , not 25 . Besides, the sitter is clearly a gentleman, not an artist. This attribution is even less tenable on account of the style, quality, and iconography of the picture, when compared to Capriolo's undistinguished documented paintings. Thus, the inscription must be referred solely to the sitter (the roebuck being part of his family coat-of-arms, or a personal emblem: e.g. roebucks and/or harts were emblems of some members of the Contarini family in Venice since the late $14^{\text {th }}$ century) and provides an obvious clue to his identification. Also the headless and almost armless antique statue of a Venus pudica in the background, clearly in the sitter's possession, might provide a useful hint, just like the view of a Quattrocento church at the end of an imposing arcade with Corinthian columns ostensibly alluding to the sitter's patrician palace. The peculiar façade of the church points to a location within the Venetian dominion and so does the known provenance of the painting. In the $17^{\text {th }}$ century it featured prominently in the famous Muselli collection in Verona as a work by Giorgione (d. 1510), and as such it was largely copied in Northern Italy up to 1587 and possibly even later. This early attribution is also untenable, but at least it acknowledges the remarkable quality of the picture. The original pose struck by the sitter was immediately imitated by Titian and even Raphael for some of their male portraits painted in the years $1513-1520$. Via them, it came to influence $17^{\text {th }}$-century French and Netherlandish portraiture, as is proven by Le Brun's Self-portrait in the Uffizi, Florence (1683), and by Rembrandt's Self-portrait (1640) at the National Gallery, London. On the other hand, its composition looks related to contemporary Central Italian portraits. If all this is correct, it points to the identification of a brilliant "Venetian" painter, well above the standards of Bartolomeo Veneto, Palma the elder, Marco Basaiti, Giovanni Cariani, Bernardino Licinio (and also of Lombard painters like Altobello Melone or the Piazzas) etc. and yet not unaware of them all. Albeit conversant with Giorgione's and Palma's work, this painter is familiar with Florentine painting as well. The fact that the sitter wears the same jacket as the young guy portrayed at about the same time in Lombardy against the background of the Lake of Iseo in a picture now in Philadelphia, equally boasting a Verona provenance suggests that they both wear a family livery, corresponding to the one of the aristocratic Capriolo family from Brescia (unrelated to the painter of the same name from Treviso). Their original fiefdoms overlooked the aforesaid Lake and included the village of Capriolo (hence their family name). Thus, its painter may well be somebody, like the Brescian painter Savoldo, whose work in the 1510s is still untraced and undocumented and who spent a period of his early life in Florence. The fact that this portrait was made in the aftermath of the bloody Sack of Brescia (February 1512) may well account for the return of the painter home to check on his family and belongings, as many other Brescian expats did.

Keywords: Domenico Capriolo; portrait of Domenico Capriolo (or Caprioli) from Brescia; Giovan Girolamo Savoldo; Muselli Collection; Verona; the sack of Brescia; 1512; Brescian collections of antiquities; State Hermitage Museum.

Название статьи. Какой Доменико? Решение загадки великолепного венецианского портрета 1512 года из собрания Государственного Эрмитажа.

Сведения об авторе. Перини Фолезани, Джованна - профессор. Урбинский университет имени Карло Бо, Палаццо Албани, ул. Браманте, 17, Урбино, Италия, 61029. giovanna.perini@uniurb.it

Аннотация. Превосходный портрет из собрания Государственного Эрмитажа, датируемый 1512 г. и приписываемый Доменико Каприоло (1494-1528), остается неразгаданной загадкой. Представленную на парапете бронзовую медаль с изображением косули (ит. capriolo) и надписью по краю «MDXII Dominicus - A.XXV» ошибочно принимают за подпись и соотносят с художником, полагая, что это автопортрет, даже несмотря на то, что в 1512 г. Каприоло из Тревизо было 18 лет, а не 25. Не говоря уже о том, что моделью, очевидно, был дворянин, а художник дворянином не был. Еще менее вероятной эта атрибуция выглядит, если принять во внимание стиль, художественное качество и иконографию документированных произведений Каприоло, не отличающихся выдающимися художественными качествами. Следовательно, надпись следует соотносить не с художником, но с моделью (косуля может быть частью герба или личной эмблемой: например, в Венеции с конца XIV в. косуля была эмблемой различных представителей семейства Контарини). Наравне с лишенной головы и рук античной статуей Венеры Пудики (Venus Pudica) на заднем плане, очевидно из коллекции изображенного человека, медаль дает ключ к определению его личности. Другая подсказка, указывающая, что речь идет о Венецианской области, - церковь эпохи кватроченто, вид на которую открывается из импозантной аркады коринфского ордера, явно демонстрирующей, что изображенный был владельцем патрицианского дворца. В XVII в. эта картина находилась в знаменитой коллекции Музелли в Вероне как работа Джорджоне (умер в 1510 г.) - в Северной Италии портрет копировали до 1587 г., а возможно, и позже. Эта ранняя атрибуция неверна, но она по крайней мере закрепляет факт признания высокого художественного досто- 
инства портрета. Своеобразная поза модели была тут же заимствована Тицианом, и даже Рафаэлем для ряда портретов, которые были написаны в 1513-1520 гг. Через них такую позу переняли французские и нидерландские портретисты XVII в., что подтверждают «Автопортрет» (1683) Ш. Лебрена из Уффици и «Автопортрет» (1640) Рембрандта из Национальной галереи в Лондоне. С другой стороны, композиция обнаруживает связь с современными портретами XVI в., исполненными в Центральной Италии.

Если все вышесказанное верно, то портрет можно атрибутировать кому-либо из блестящих венецианских художников, превосходящему Бартоломео Венето, Якопо Пальму Старшего, Марко Базаити, Джованни Кариани, Бернардино Личинио (а также ломбардских мастеров, например, Альтобелло Мелоне или Пьяцца) и др., но при этом знакомому с их творческими поисками. Хотя этому художнику близки художественные установки Джорджоне и Пальмы, он не чужд и флорентийских идей. Костюм модели близок к тому, что можно видеть на молодом человеке с портрета на фоне озера Изео в Ломбардии (из Филадельфии), причем этот портрет - также веронского происхождения, и это предполагает, что оба героя представлены в колете цветов аристократической семьи Каприоло из Брешии (не связанной с художником-однофамильцем из Тревизо). Их вотчины выходили на вышеупомянутое озеро и включали деревню Каприоло (отсюда - фамилия). Возможно, портрет написал кто-либо из брешианских мастеров (подобных Савольдо), чье творчество 1510-х годов мало документировано и до сих пор мало известно, и кто жил в юности во Флоренции. Тот факт, что этот портрет был сделан после кровавой осады Брешии (февраль 1512 г.), вполне можно объяснить возвращением художника домой, чтобы проведать семью и собственность, как это делали многие другие изгнанники.

Ключевые слова: Доменико Каприоло; портрет Доменико Каприоло (или Каприоли) из Брешии; Джован Джироламо Савольдо; коллекция Муселли; Верона; осада Брешии; 1512; Брешианские коллекции древностей; Государственный Эрмитаж. 